INTERNATIONAL JOURNAL OF

MULTIDISCIPLINARY STUDIES IN ARCHITECTURE

AND CULTURAL HERITAGE

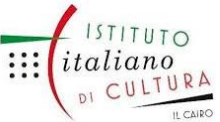

ISSN: $2735-4415$

VOLUME 2, ISSUE 2, 2019, $61-20$.

www.egyptfuture.org/ojs/

\title{
Study of Wood Gap Fillers with the Application on Archaeological Artifacts
}

Hager S. Saeed a, Mennat- allah G. El-sayed a, Aya M. Saeed a, Amina A.

Mohamed a, Bassant H. El-sayed a, Mourad F. Mohamed a, *

a Conservation Department, Faculty of Archaeology, Cairo University

\begin{abstract}
A wide range of materials has been used for gap filling in wooden objects but very little information exists in the literature on their suitability. In this paper 10 gap filling materials were tested for their mechanical properties, $\mathrm{pH}$ value and the degree of contraction. The results of the study showed that two types of the fill gave high mechanical properties and $\mathrm{pH}$ values were near to those of wood. Two of the tested gap fillers were chosen for application on two selected archaeological wooden artifacts.

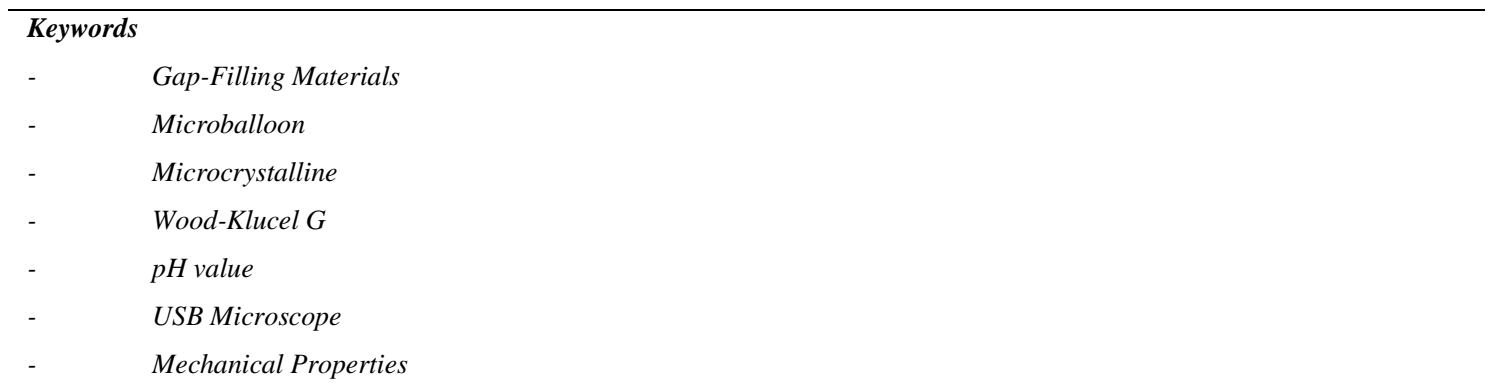

\section{Introduction}

Wood is one of the most used constituent materials for art objects. The historical wooden heritage is huge and varied. But this material is very sensitive to decay and several kinds of degradative processes can attack it (Unger, schniewind, \& Unger, 2001)(Cleary, 2014) Chemical, physical, biological or mechanical decay leads to similar effects on wood, in particular it promotes the reduction of its mechanical strength. The main purpose of conservation is to preserve art and other artifacts in such a condition that coming generations may experience them and study their value. The filling of the wooden objects is the operation through which missing parts are 
completed and the degraded ones replaced to protect it from continuous damage.

In this paper the saw dust was used to prepare gap-filling materials because itimproves stability of dimensions and reduces deflation rate. The weight of the filling material and thermal expansion are appropriate, but it is a hygroscopic material and when moisture content increases microbiological infection can occur. (abdallah, 2014). Two parts of sawdust and one part of filter paper was used with carboxymethylcellulose sodium salt (2\%) to refill gaps and cracks in two coffins at theEgyptian Museum of the Faculty of Archaeology - Cairo University (Elhadid, 1998). Sawdust and chalk dust mixed with animal glue was used to fill gaps in an icon panel (Hutanu, Sandu, Vasilache, \& Nice, 2003). Sawdust and calcium carbonate was mixedwith polyvinyl acetate to fill gaps in a Chinese Altar (Cornu, Villalon, Carreras, Mejias,\& Alvarez, 2001)

Microballoon is an inert material, compressible and non-toxic, it is used to give a strong and light homogeneous mixture, it is easy to apply and shape and it helps prevent shrinkage of the mixture after drying (Loqma, 1999). Microballoon and epoxy were used as a mixture and four ratios of epoxy resin to microballoon were chosen: 0.5 to 1,1 to $1,1.5$ to 1 and 2 to 1 by weight and the best result was 1 to 1 mixture because it has a compressive strength below that of the wood, is easily shaped using woodworker's 
carving tools and is capable of holding very fine detail (Barday \& Mathias, 1989). Microballoon and B-72 15\% in ethyl alcohol 1:1 were usedto fill water sensitive objects. Fills were found to be easily built up, strong, lightweight, and easily shaped by sanding, carving, or application of appropriate solvents. Fills may be in-painted with water-based acrylics such as Liquitex, or with watercolors (Hatchfield \& Pamela, 2013). Microballoon was used with silicone rubber and epoxy as gap-fillers and both the gap-fillers were strong, easily workable, easily paintable and matched to their application with ease of shaping and inpainting(Grattan \& Barclay, 1988)

Klucel $\mathrm{G}$ was used in a 7\% percentage in ethylalcohol and it was mixed with microballoon and pigents and used to fill cracks and gaps in an old colored Egyptian coffin (Johanson, Head, \& Green, 1995). Klucel (hydroxyl propyl cellulose) (HPC) is nonionic water-soluble cellulose ether with a remarkable combination of properties. It combines organic solvent solubility and stabilizing properties characteristic of other water-soluble cellulose polymers (Aqualon). Klucel is nontoxic, chemically neutral, reversible with water and ethanol, very good resistance to biological and chemical decomposition, constanct $\mathrm{pH}$ value and completely transparent when dry (Arkivprodukter). Wishab sponge (vulcanized latex sponge with magnesium silicate filler) and Klucel G. $15 \%$ in IMS was applied in conjunction with Japanese tissue paper as a protective facing for cracks during conservation of an Egyptian coffin and the discoloration is only noted in areas where 
Klucel G had been previously applied (Hallett). The ground of the 16th/17th Century Icon representing the Virgin and Child was reconstructed using Klucel $10 \%$ in ethanol, as binding agent, and Champagne chalk, as filler (Matijević \& Lipanović, 2009). The stuccos based on cellulose ethers dissolved in the mixture of $50 \%$ water and ethanol (Klucel $\mathrm{G}$ and Tylose MH300 P) were the best materials to refill the Christ's heel (Bartolone, Sebastianelli, Di Carlo, Barresi, Palla, \& Megna, 2017)

MCC was selected for its well-known reinforcing properties and its chemical affinity with wood having the same chemical composition. More-over, MCC is easy to source; conservators can handily use it because it does not require any other chemical process to be applied (Cataldia, Esposito, Frigioneb, \& Pegorettia, 2016) (Thummanukitcharoen, Srikulkit, \& Limpanart, 2012) (Spoljaric, Genovese, \& Shanks, 2009).Two types of historical wood (18th century) (Juglans regia and Abies alba) presenting different degradation Conditions were consolidated through acetone solutions of micro composites consisting of a commercial polymer (Paraloid B72)

often used for wood consolidation and two different amounts $(5$ and $30 \mathrm{wt}$ \%) ofmicrocrystalline cellulose (MCC) (Cataldia, Esposito, Frigioneb, \& Pegorettia, 2016) 
INTERNATIONAL JOURNAL OF

MULTIDISCIPLINARY STUDIES IN ARCHITECTURE

AND CULTURAL HERITAGE

\section{Materials and methods}

\subsection{Materials}

Table (1) all materials that used to prepare the samples

\begin{tabular}{|l|l|l|}
\hline Material & Usage & Notes \\
\hline Klucel G & Used as a binder & $\begin{array}{l}\text { Hydroxypropylcellulose } \\
\text {,CTS }\end{array}$ \\
\hline Microballoon & Used as filler & CTS \\
\hline $\begin{array}{l}\text { Microcrystalline cellulose } \\
\text { MCC) }\end{array}$ & used as a filler & $\begin{array}{l}\text { Composed of glucose units } \\
\text { Deffner\&Johann, Germany }\end{array}$ \\
\hline Soft saw dust & used as a filler & Pinus halepensis L. \\
\hline Hard saw dust & used as a filler & beech wood \\
\hline Balsa saw dust & used as a filler & Balsa L. \\
\hline Ethylalcohol 95\% & Used as Klucel solvent & $\begin{array}{l}\text { Elnasr pharmaceutical } \\
\text { chemicals company }\end{array}$ \\
\hline Distilled water & Used in pH measurement & $\begin{array}{l}\text { Free from all salts }-\mathrm{pH} \\
(6.5-6.8)\end{array}$ \\
\hline
\end{tabular}




\subsection{Methods}

\subsubsection{Klucel G}

Klucel $G$ was prepared in a 5\% percentage in ethylalcohol (w/v) and the solutionwas suitable for use after two days.

Table (2) ratios of materials used in preparation of samples

\begin{tabular}{|c|c|c|}
\hline Sample name & Filler mixture (by volume) & Filler to binder (by volume) \\
\hline Microballoon1 & $\begin{array}{c}\text { softwood dust and } \\
\text { microballoon (1:1) }\end{array}$ & $(3: 2)$ \\
\hline Microballoon2 & $\begin{array}{c}\text { softwood dust and } \\
\text { microballoon (2:1) }\end{array}$ & $(1: 1)$ \\
\hline $\begin{array}{c}\text { Hard wood dust } \\
1\end{array}$ & $\begin{array}{c}\text { Softwood dust and hardwood } \\
\text { dust (1:2) }\end{array}$ & \\
\hline
\end{tabular}


INTERNATIONAL JOURNAL OF

MULTIDISCIPLINARY STUDIES IN ARCHITECTURE

AND CULTURAL HERITAGE

\begin{tabular}{|c|c|c|}
\hline $\begin{array}{c}\text { Hard wood dust } \\
2\end{array}$ & $\begin{array}{c}\text { Softwood dust and hardwood } \\
\text { dust (2:1) }\end{array}$ & $(1: 1)$ \\
\hline $\begin{array}{c}\text { Hard wood dust } \\
3\end{array}$ & $\begin{array}{c}\text { Softwood dust and hardwood } \\
\text { dust (1:1) }\end{array}$ & $(1: 1)$ \\
\hline Balsa wood 1 & $\begin{array}{c}\text { Softwood dust and Balsa wood } \\
\text { dust (1:2) }\end{array}$ & $(1: 1)$ \\
\hline Balsa wood 2 & $\begin{array}{c}\text { Softwood dust and Balsa wood } \\
\text { dust (1:1) }\end{array}$ & $(1: 1)$ \\
\hline $\begin{array}{c}\text { Microcrystalline } \\
1\end{array}$ & $\begin{array}{c}\text { Softwood dust and } \\
\text { Microcrystalline (2:1) }\end{array}$ & $(1: 1)$ \\
\hline $\begin{array}{l}\text { Microcrystalline } \\
2\end{array}$ & $\begin{array}{c}\text { Softwood dust and } \\
\text { Microcrystalline (1:1) }\end{array}$ & $(3: 2)$ \\
\hline $\begin{array}{l}\text { Microcrystalline } \\
3\end{array}$ & $\begin{array}{c}\text { Softwood dust and } \\
\text { Microcrystalline (2:3) }\end{array}$ & \\
\hline
\end{tabular}

\subsubsection{Digital microscope}

The photos of samples surfaces were taken by USB digital microscope (Rohs, 1200X) 


\subsubsection{PH meter}

The $\mathrm{pH}$ of samples was determined by an extraction method; and waterproof $\mathrm{pH}$ - temp pocket tester with replaceable probe were used (Adwa). The samples were ground into powder. And $2 \mathrm{~g}$ of powder was added to $50 \mathrm{ml}$ of boiling de-ionized water and stirred for 5 minutes in a tester. The mixture was standing in the closed tester for 30 minutes and was cooled to room temperature. The extract was filtered and $\mathrm{pH}$ of the solution was measured with $\mathrm{pH}$ meter (Humar, Patric, \& et, 2001)

\subsubsection{Compressive strength}

H5KT/ 130-5000N [ASD 3787 ASTM Ball TEST TSX-2O]

\subsubsection{Samples aging}

Thermal aging was done on samples at $80^{\circ} \mathrm{C}$ and $65 \% \mathrm{RH}$ for 120 hours (5 days) which is equivalent to 25 years of an objects lifetime (Binder dry oven with digital indicator, model no. 92403000002000) (Kaminska, Sawczak, \& Ciepeliniski, 2004)(Arias, 2013)(Pentzien, Conradi, \& Krüger, 2011) to find out if the $\mathrm{pH}$ value and mechanical properties were affected by artificial aging.

\section{Results and discussion}




\subsection{Visual inspection}

* All the samples after drying, had many cracks, and their mechanical properties were bad, except for four samples: microballoon 1, microballoon 2, microcrystalline 2 and microcrystalline 3 had good mechanical properties.

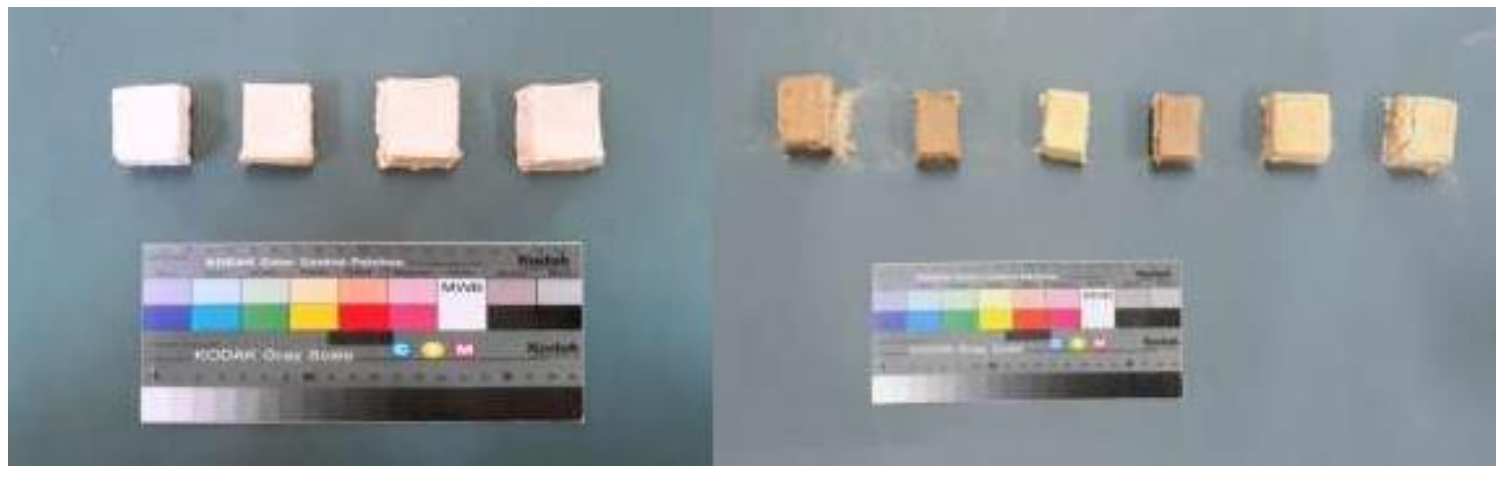

Fig (1) Samples that gave good results from left to right: microcrystalline 3 , microcrystalline 2, microballoon 2 and microballoon 1 Fig (2) Samples that failed to give good results from left to right: hard saw dust 1 , hard saw dust 2, microcrystalline 1, hard saw dust 3, balsa wood 1and balsa wood 2 


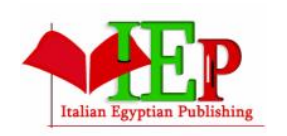

ISSN: 2735-4415

\section{INTERNATIONAL JOURNAL OF \\ MULTIDISCIPLINARY STUDIES IN ARCHITECTURE \\ AND CULTURAL HERITAGE}

VOLUME 2, ISSUE 2, 2019, $61-20$.

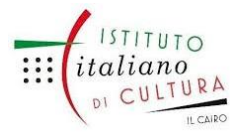

www.egyptfuture.org/ojs/

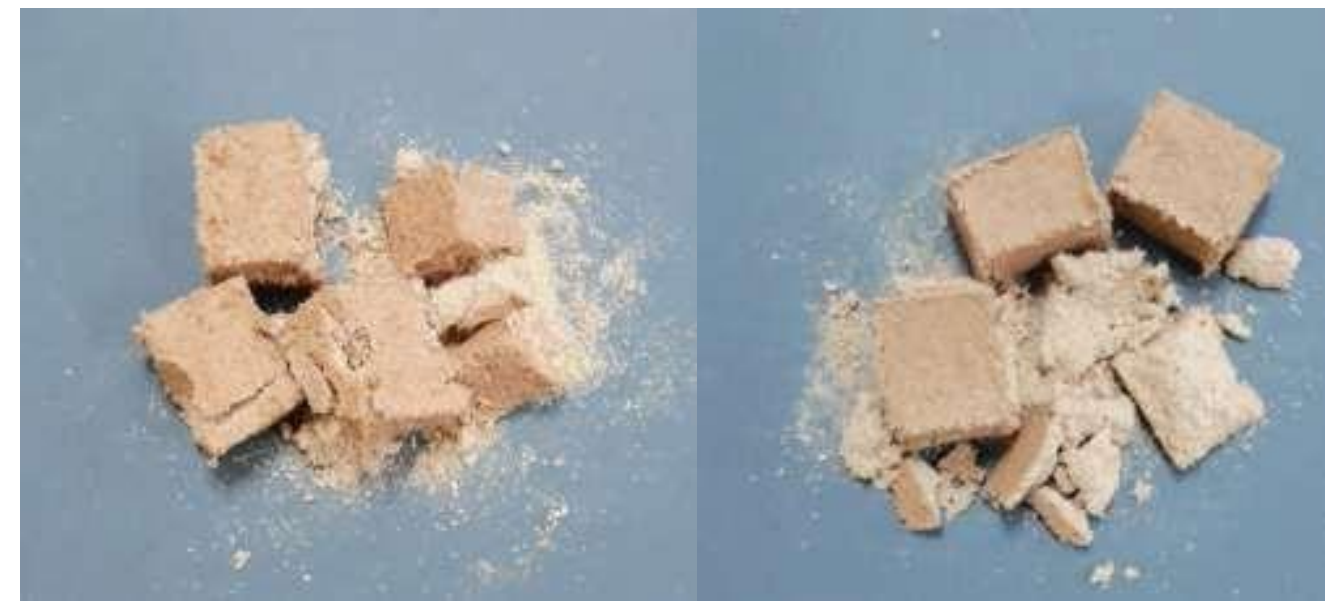

Fig (3) hard saw dust 1

Fig (4) hard saw dust 2
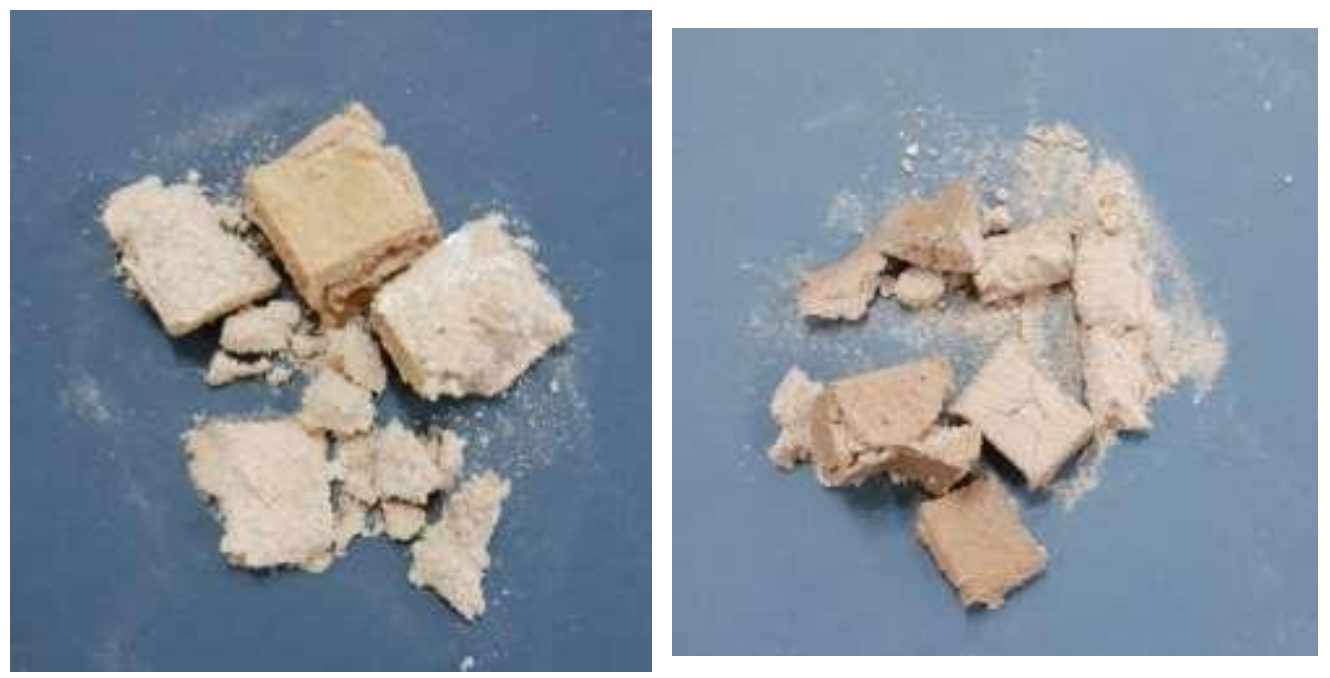
INTERNATIONAL JOURNAL OF

MULTIDISCIPLINARY STUDIES IN ARCHITECTURE

AND CULTURAL HERITAGE

Fig (5) microcrystalline 1

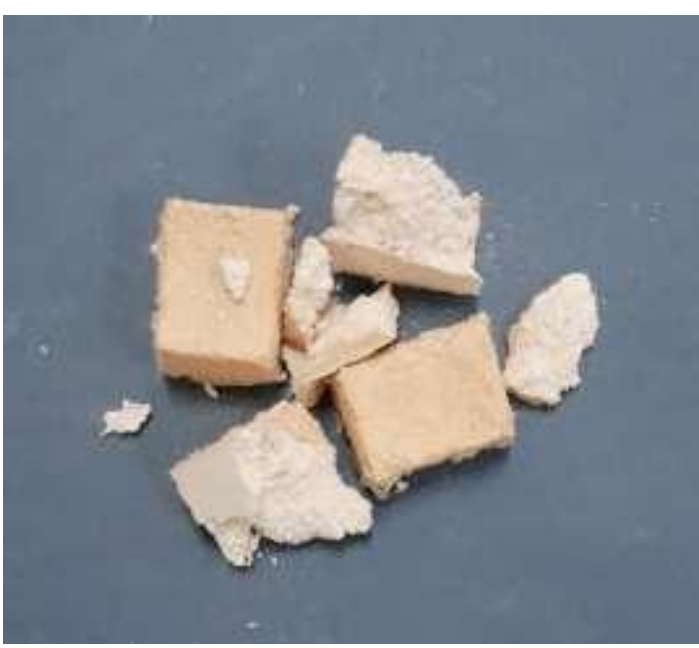

Fig (7) balsa wood 1
Fig (6) hard saw dust 3

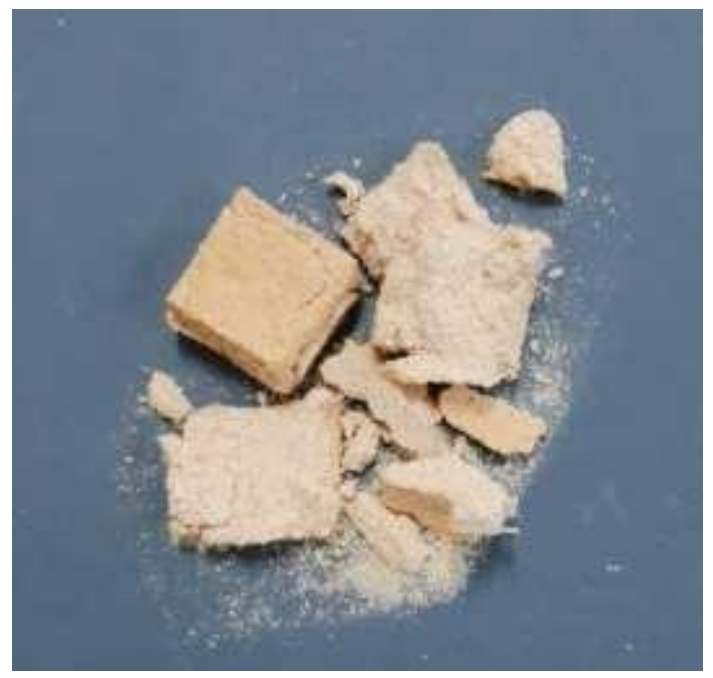

Fig (8) balsa wood 2

Microcrystalline samples were better than microballoon samples during surface examination. Microcrystalline samples had narrow pores.

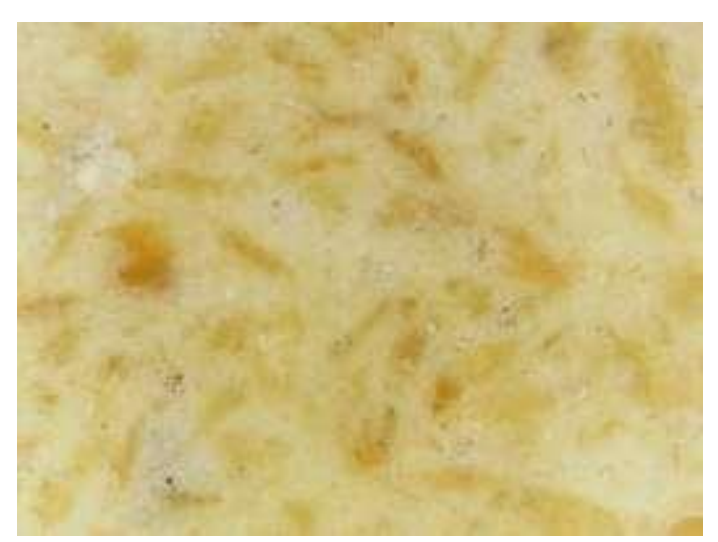




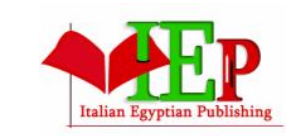

ISSN: $2735-4415$

\section{INTERNATIONAL JOURNAL OF \\ MULTIDISCIPLINARY STUDIES IN ARCHITECTURE \\ AND CULTURAL HERITAGE}

VOLUME 2, ISSUE 2, 2019, $61-20$.

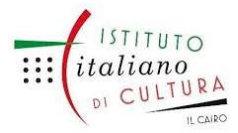

www.egyptfuture.org/ojs/
Fig (9)USB microscope image of microballoon 1before aging of microballoon 2

before aging

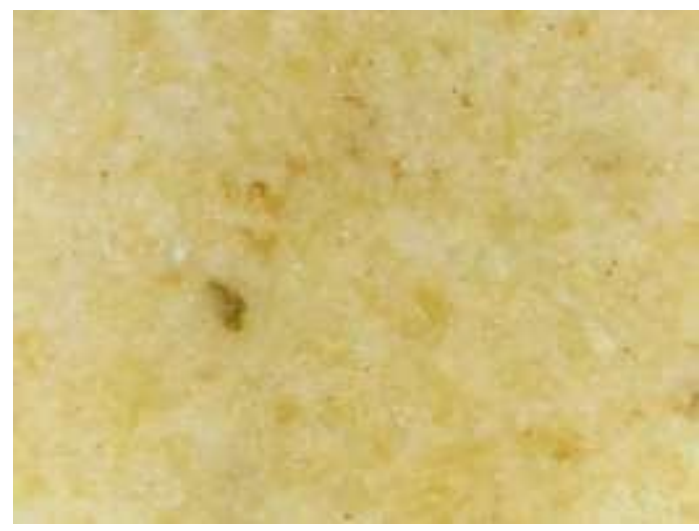

Fig (10)USB microscope image

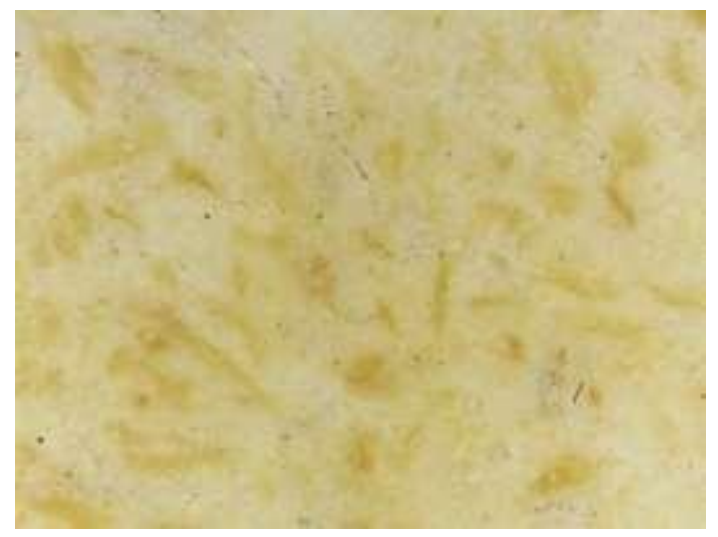

Fig(11)USB microscope image ofmicrocrystalline2 before aging Fig(12) USB microscope image ofmicrocrystalline 3 before aging 


\subsection{Determination of the $\mathrm{pH}$ value}

The $\mathrm{pH}$ of microcrystalline samples was close to the $\mathrm{pH}$ of the wood

.The $\mathrm{pH}$ ofmicroballoon samples was high due to microballoon alkalinity.

Table (3) the $\mathrm{pH}$ value of samples before and after aging

\begin{tabular}{|c|c|c|}
\hline samples & $\begin{array}{c}\text { The } \mathrm{pH} \text { value } \\
\text { before aging }\end{array}$ & $\begin{array}{c}\text { The } \mathrm{pH} \text { value } \\
\text { after aging }\end{array}$ \\
\hline Soft wood dust & 4.3 & - \\
\hline Microballoon & 9.0 & - \\
\hline microcrystalline & 5.8 & - \\
\hline Microballoon 1 & 8.2 & 8.8 \\
\hline Microballoon 2 & 8.1 & 8.3 \\
\hline Microcrystalline 2 & 4.7 & 4.8 \\
\hline Microcrystalline 3 & 4.6 & 4.8 \\
\hline
\end{tabular}

\subsection{The degree of contraction}

Microcrystalline and microballoon samples did not shrink after drying 
INTERNATIONAL JOURNAL OF

MULTIDISCIPLINARY STUDIES IN ARCHITECTURE

AND CULTURAL HERITAGE
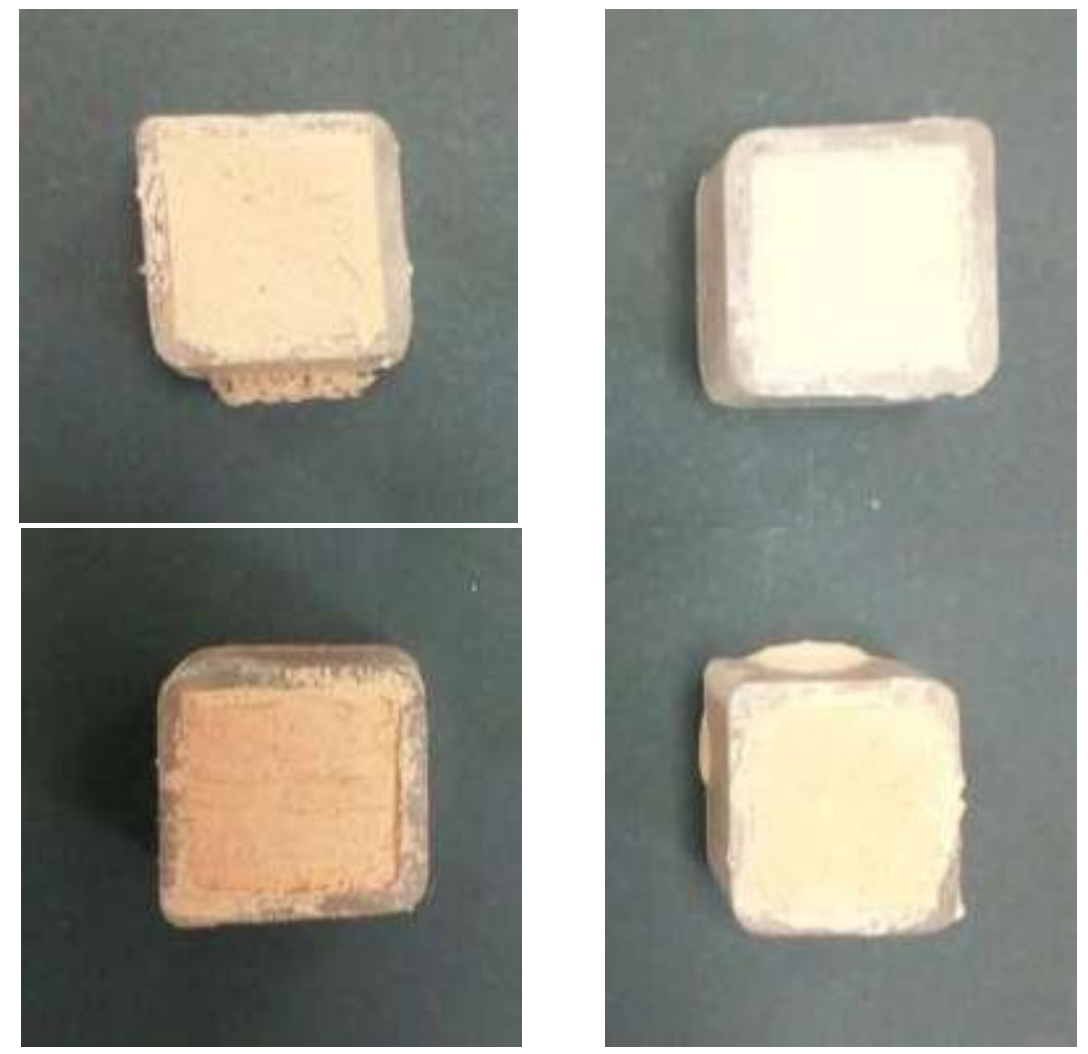

Fig (13) microballoon 1, microballoon 2, microcrystalline2 and microcrystalline3 after drying in acrylic molds

\subsection{Compressive strength}


Microcrystalline 3 was the highest in compressive strength test followed bymicrocrystalline 2, microballoon 1 and microballoon 2.

Table (5) compressive strength of samples

\begin{tabular}{|c|c|}
\hline samples & compressive strength(kgf) \\
\hline Microballoon 1 & 15.52 \\
\hline Microballoon 2 & 10.41 \\
\hline Microcrystalline 2 & 15.95 \\
\hline Microcrystalline 3 & 32.22 \\
\hline
\end{tabular}

\section{Sterilization of raw materials}

Raw materials was sterilized before application on the selected wooden object using steaming with essential oil; clove oil was used in microballoon, microcrystalline and saw dust sterilization. 


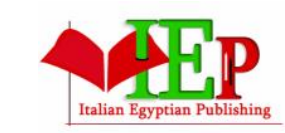

ISSN: $2735-4415$

\section{INTERNATIONAL JOURNAL OF \\ MULTIDISCIPLINARY STUDIES IN ARCHITECTURE \\ AND CULTURAL HERITAGE}

VOLUME 2, ISSUE 2, 2019, 61 - 20.

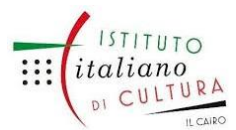

www.egyptfuture.org/ojs/

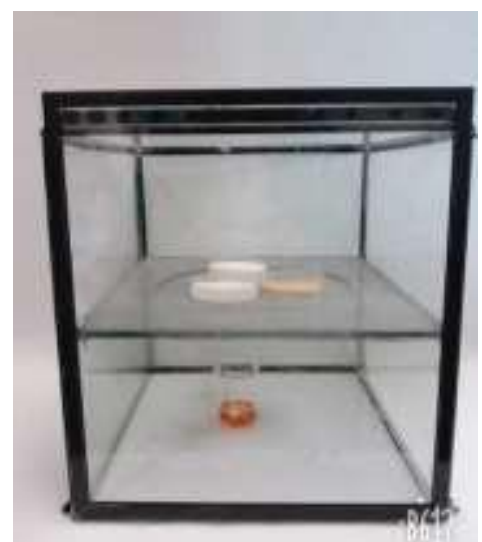

Fig (14) sterilization of raw materials using clove essential oil

\section{Applying on selected wooden artifacts}

\subsection{A historic wooden box}

Microcrystalline 2 was selected to re-fill gaps in a selected wooden box dating from 1945. So, microcrystalline cellulose and soft wood dust were mixed and used as filler (1:1 by volume) and then it was mixed with Klucel $\mathrm{G}$ as a binder (3:2 by volume) 
After filling gaps Klucel $G$ was applied as a thin layer over the refilled areas, thewater colors were used to give the refilled parts a color close to that of wood

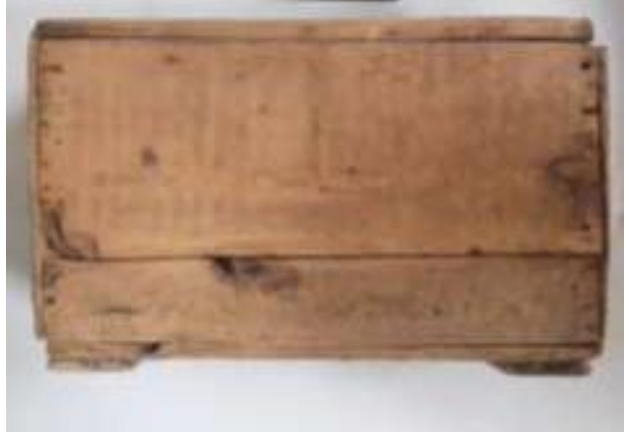

Fig (15) the front part before gap filling

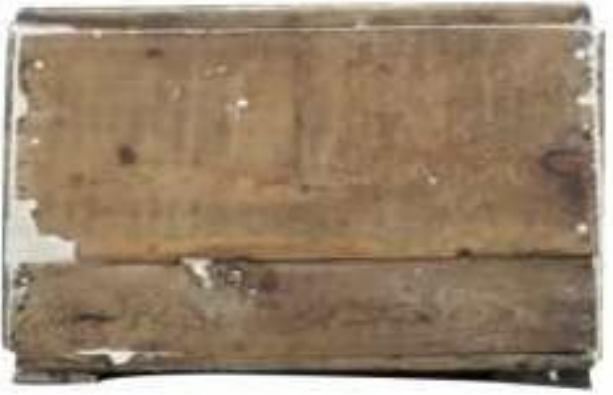

Fig (17) the front part after re-filling gaps

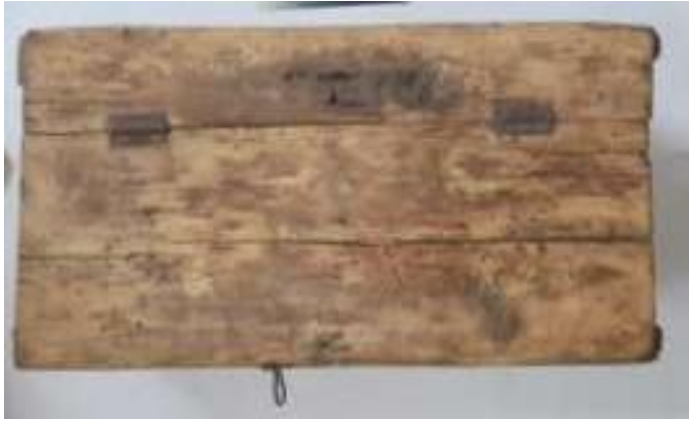

Fig (16) the upper part before gap filling

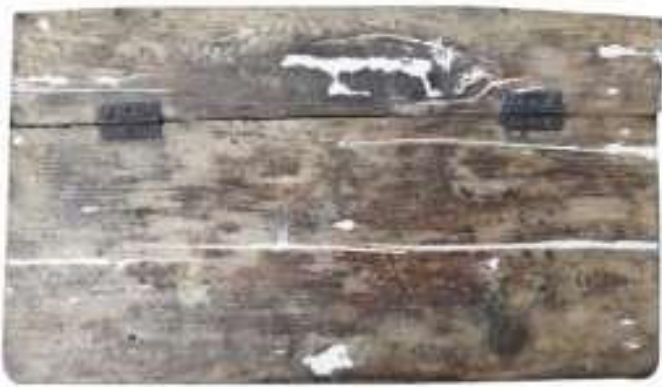

Fig (18) the upper part after re-filling gaps 
INTERNATIONAL JOURNAL OF

MULTIDISCIPLINARY STUDIES IN ARCHITECTURE

AND CULTURAL HERITAGE

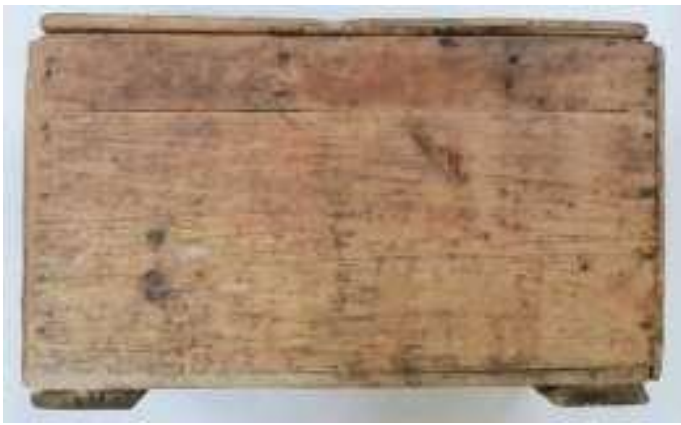

Fig (19) the front part after re-coloring

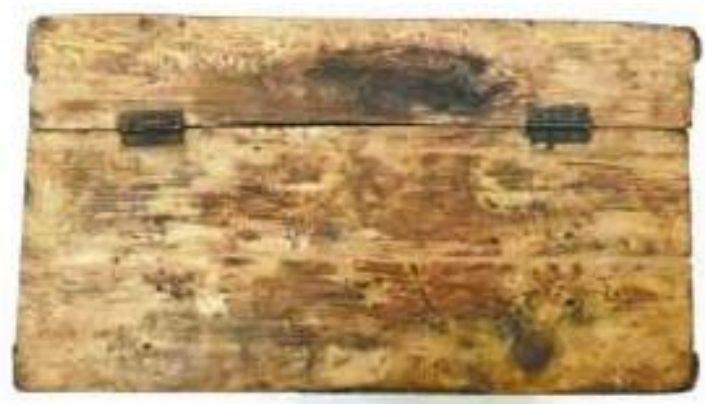

Fig (20) the upper part after re-coloring

\subsection{A gilded wooden artifact from the Manial Museum}

In this object Microcrystalline 3 was selected to re-fill gaps. So, microcrystalline cellulose and softwood dust were mixed and used as filler $(2: 3 \mathrm{~V} / \mathrm{V})$ and then it was mixed with Klucel $\mathrm{G}$ as a binder (1:1 V/V)
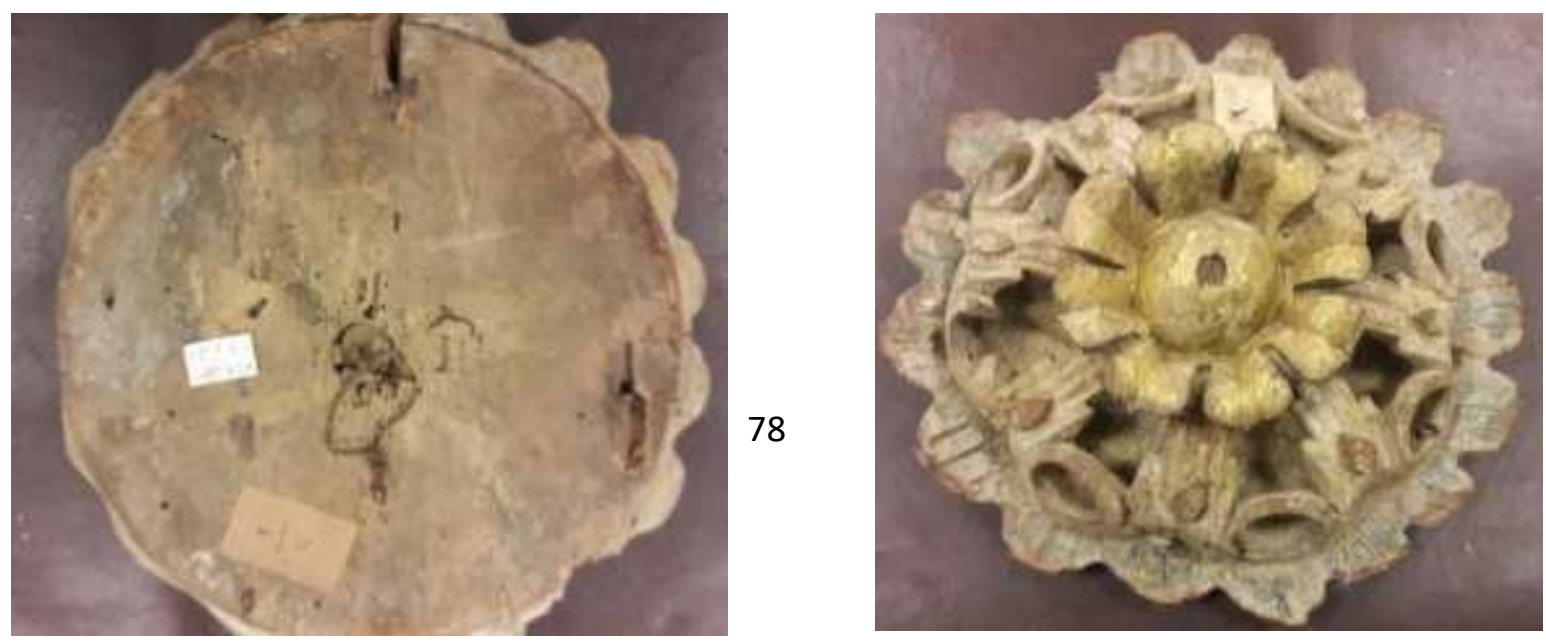
Fig (21) the back face before gap-filling Fig (22) the front face before gap- filling
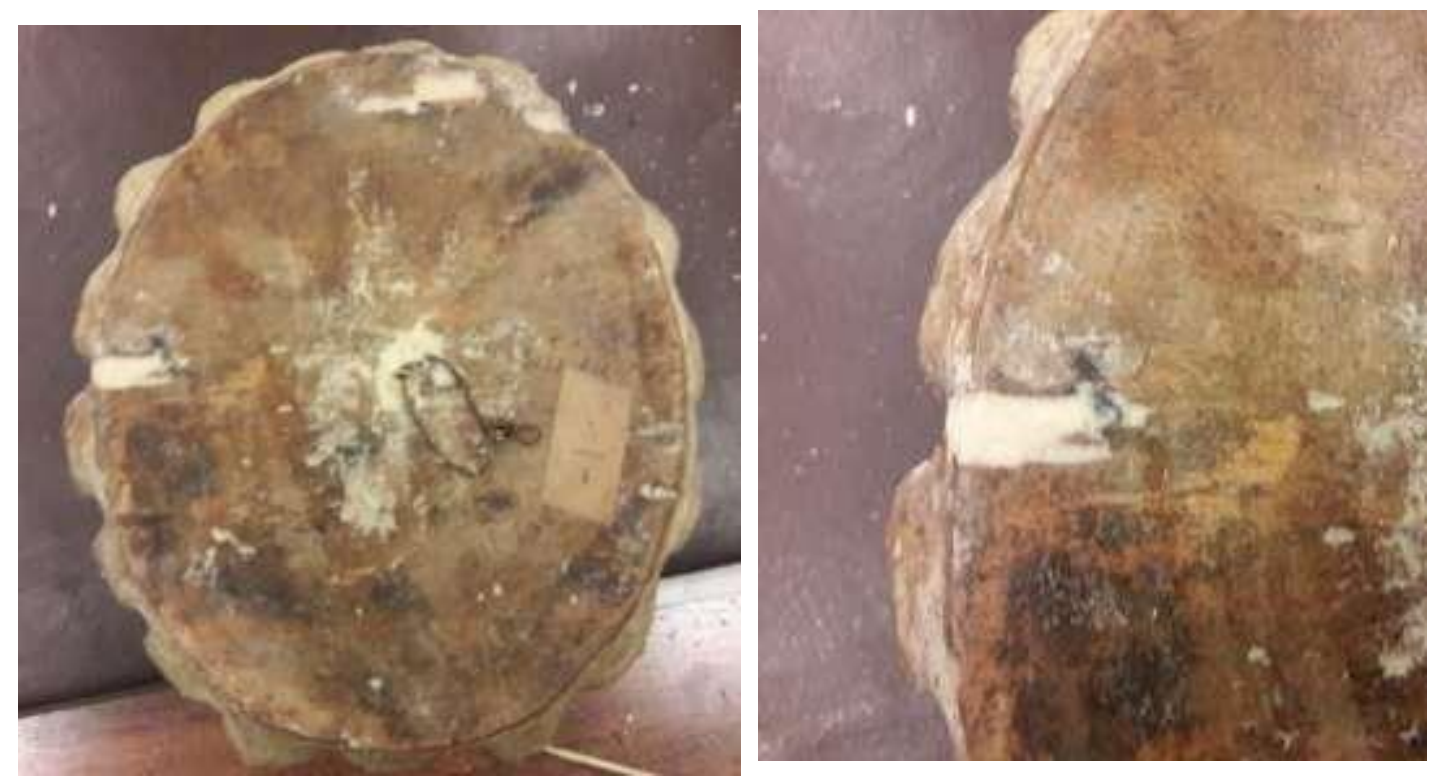

Fig (23) the back face after re-filling Fig (24) the back face after re-filling

\section{Conclusion}

The paper describes ten wood gap-filling materials. Four of them gave excellent results and six gave bad results. The results of digital microscope show that microcrystalline samples were better than microballoon samples during surface examination. The $\mathrm{pH}$ of microcrystalline samples was close to the $\mathrm{pH}$ of the wood unlike microballoon samples, Microcrystalline and 
microballoon samples did not shrink after drying. Microcrystalline and softwood dust at (2:3) ratio with Klucel at (1:1) ratio was the highest in compressive strength test and was the least in the $\mathrm{pH}$ value, followed by Microcrystalline and softwood dust at (1:1) ratio with Klucel at(3:2)ratio, microballoon and softwood dust at (1:1) ratio with Klucel at (3:2) ratio and microballoon and softwood dust at (2:1) ratio with Klucel at (3:2) ratio.

As a result of our work it is possible to say that the ideal gap-fillers were Microcrystalline and softwood dust at (2:3) ratio with Klucel at (1:1) ratio and is preferable to use in large objects and Microcrystalline and softwood dust at (1:1) ratio with Klucel at (3:2) ratio and is preferable to use in small objects.

\section{Acknowledgents:}

Many thanks to Prof. Dr. Nesrin El Hadidi, Ms. Rehab Gomaa the conservation head of the Manial Museum and Ms. Ghada Gamal for their support throughout this work.

\section{References:}


Abdallah, M. (2014). Evalution And Modification of Filler pastes used in the ReinforcementCompletion of moveable Archaeological Wooden Artifacts. Cairo: Faculty of Archeology Cairo University.

Arias, T. (2013). Conservation of Historic Book Bindings by Means of Facsimile Reproduction:The Torres Notarial Register (1382-1400) in the Archive of the Royal Chancellery of Granada, Spain. Science and Technology for the Conservation of Cultural Heritage, 227-230.

Barday, R., \& Mathias, C. (1989). An epoxy microbaloon mixture for gap filling in woodenobjects. Jaic, 31-42.

Bartolone, F., Sebastianelli, M., Di Carlo, E., Barresi, G., Palla, F., \& Megna, B. (2017). Newapplications in the use of cellulose pulp for the integration of wooden supports. Conservation science in cultural heritage, 121-133.

Cataldia, A., Esposito, C., Frigioneb, M., \& Pegorettia, A. (2016). Photocurable resin/microcrystalline cellulose composites for woodprotection: Physicalmechanicalcharacterization. Elsevier, 230-239.

Cleary, R. (2014). Considering the Use of Epoxies in the Repair of Historic Structural Timber. 
INTERNATIONAL JOURNAL OF

MULTIDISCIPLINARY STUDIES IN ARCHITECTURE

AND CULTURAL HERITAGE

Pennsylvania: University of Pennsylvania.

Cornu, E., Villalon, A., Carreras, R., Mejias, A., \& Alvarez, L. (2001). Wood Conservation inCuba: Treatment of a Chinese Altar in La Habana Vieja. Wag Postprints.

El Hadidi, N.M.N. (1998). Treatment and Conservation of Wood - Application on Two Coffinsat the Egyptian Museum of the Faculty of Archaeology Cairo University. Cairo: Faculty of archaeology cairo university.

Grattan, D., \& Barclay, R. (1988). A Study Of Gap-fillers For Wooden Objects. Studies inConservation, 71- 86.

Hallett, K. (n.d.). Analysis of Discolouration on Egyptian Coffin 22814. The British Museum.

Hatchfield, \& Pamela. (2013). Note on a fill material for water sensitive objects. Journal of the American Institute for Conservation, 93-96.

Humar, M., Patric, M., \& et. (2001). Changes of the $\mathrm{pH}$ value of impregnated wood duringexposure to wood-rotting fungi. Springer, 288-293. 
INTERNATIONAL JOURNAL OF

MULTIDISCIPLINARY STUDIES IN ARCHITECTURE

AND CULTURAL HERITAGE

Hutanu, I., Sandu, I., Vasilache, V., \& Nice, L. (2003). Studies on wood consolidation andcompleting gaps in panel paintings. Pro lingo, 299305.

Johanson, C., Head, K., \& Green, L. (1995). The Conservation of a polychrome egyptiancoffin. Studies in conservation", 73-81.

Kaminska, A., Sawczak, M., \& Ciepeliniski, M. (2004). Colorimetric Study of the Post- Processing effect due to Pulsed Laser Cleaning of Paper. Optica Applicata, 121-132.

Loqma, N. (1999). Study of treatment and maintenance of dry wood applied to a selection ofwood sculptures from. Cairo: Faculty of Archaeology Cairo University.

Matijević, J., \& Lipanović, I. (2009). Conservation-Restoration Treatment of the 16th/17thCentury Icon Representing the Virgin and Child. Croatia: The Arts Academyof the University of Split Department of RestorationConservation.

Pentzien, S., Conradi, A., \& Krüger. (2011). The Influence of Paper Type and State of Degradation on Laser Cleaning of Artificially Soiled Paper. Lasers in the Conservationof Artworks, 59-65. 
INTERNATIONAL JOURNAL OF

MULTIDISCIPLINARY STUDIES IN ARCHITECTURE

AND CULTURAL HERITAGE

Spoljaric, S., Genovese, A., \& Shanks, R. (2009). Polypropylenemicrocrystalline cellulosecomposites with enhanced compatibility and properties. Elsevier, 791-799.

Thummanukitcharoen, P., Srikulkit, K., \& Limpanart, S. (2012). Preparation of organosilane treated microcrystalline cellulose (SiMCC)and The Polypropylene/SiMCC Composite.Journal Of Metals, Materials And Minerals, 13-19.

Unger, A., schniewind, A., \& Unger, W. (2001). Conservation of Wood Artifacts. Berlin:Springer.

Received: February 15, 2018

Accepted: April 20, 2018 